\title{
ANALISIS CLUSTER MENGGUNAKAN ALGORITMA K-MEANS CLUSTER UNTUK CULSTERING JENIS PENYAKIT MENULAR PADA PUSKESMAS DI KECAMATAN KOTA TANGERANG
}

\section{CLUSTER ANALYSIS USING K-MEANS CLUSTER ALGORITHM FOR CLUSTERING TYPES OF TRANSMITTED DISEASE IN HEALTH CENTER IN KECAMATAN KOTA TANGERANG}

\author{
Aninda Rachman ${ }^{1)}$, Aden, S.Si., M.Pd. ${ }^{2)}$, dan Yulianti Rusdiana, S.Si., M.Sc ${ }^{3)}$ \\ 1) 2) 3) Program Studi Matematika, FMIPA Universitas Pamulang, Kampus 2 \\ Jl. Raya Puspitek No.46, Buaran, Serpong \\ Email : rachmananinda@gmail.com
}

\begin{abstract}
The research in this paper aims to cluster the types of diseases in the sub-district Puskesmas in the city of Tangerang, to facilitate the handling and improvement of the environment, and to find out which disease is the most dominant in each cluster, during clustering at the sub-district Puskesmas in Tangerang City. The subject of this research is the result of clustering of infectious diseases with the method used is Cluster Analysis using the K-means Cluster Algorithm using calculations using SPSS 22. And the results of this study can find out the type of disease with each Puskesmas according to the sub-district, for which clusters are determined there are four clusters where each cluster is a type of infectious disease itself, namely pulmonary Tuberculosis, pneumonia, dengue, and diarrhea, for each cluster each divided according to its sub-district or Puskesmas. With these results, it can be concluded that the clustering results know which sub-districts have contracted infectious diseases according to the cluster formed.

Keywords : Cluster Analysis, K-means Cluster Algorithm, Types of Infectious Diseases, Puskesmas Tangerang City, SPSS 22.

ABSTRAK

Penelitian ini bertujuan untuk Clustering jenis penyakit pada Puskesmas perkecamatan di Kota Tangerang, untuk memudahkan penanganan dan perbaikan lingkungan, Serta mencari jenis penyakit mana yang paling dominan pada masing-masing klaster, saat pengklasteran pada puskesmas perkecamatan di Kota Tangerang. Subjek penelitian ini adalah hasil dari pengklasteran jenis penyakit menular dengan metode yang digunakan adalah Analisis Klaster menggunakan Algoritma K-means Klaster dengan perhitungan menggunakan Aplikasi SPSS 22. Dan hasil penelitian ini dapat mengetahui jenis penyakit dengan masing-masing puskesmas sesuai kecamatan, untuk itu klaster ditentukan ada empat klaster dimana setiap klaster adalah jenis penyakit menular itu sendiri yaitu TB Paru, Pneumonia, DBD, dan Diare, untuk setiap klaster masing-masing terbagi sesuai kecamatannya atau puskesmanya. Dengan hasil tersebut dapat disimpulkan bahwa hasil pengklasteran mengetahui kecamatan mana saja yang terjangkit penyakit menular sesuai klaster yang terbentuk.
\end{abstract}

Kata kunci : Analisis Klaster, Algoritma K-means Klaster, Jenis Penyakit Menular, Puskesmas Kota Tangerang, SPSS 22.

\section{PENDAHULUAN}

Kota Tangerang memiliki luas 164,55\% dengan jumlah kecamatan 13 dan 104 Kelurahan, jumlah penduduk sebanyak 2.093.706 jiwa, dan Kota Tangerang memiliki tingkat kepadatan penduduk sebesar $12.724 \mathrm{jiwa} / \mathrm{km} 2$. dengan jumlah dan kepadatan penduduk yang cukup padat lingkungan Kota Tangerang pun memiliki penyebaran penyakit dari data 30 Puskesmas yang ada di Kota Tangerang. Jenis Penyebaran penyakit menular diantaranya TB Paru yang memang akan sangat mudah menyebar lewat percikan ludah lewat udara, jika kepadatan penduduk cukup padat sehingga ruang udarapun akan sedikit, sehingga penyebaran lewat udara akan sangat mudah penyebarannya, Pneumonia sama halnya dengan TB Paru penyebaran terjadi lewat percikan air liur lewat udara, DBD penyakit ini tergantung dengan kebersihan lingkungan sekitar dan 
penyebarannya lewat gigitan nyamuk aedes aegypti berkembangbiak pada lingkungan kotor untuk itu jika jumlah penduduk banyak semakin banyak juga pemanfaatan lingkungan yang erpakai sehingga lingkungan padat penduduk pun tidak bisa dihindari dari lingkungan kotor, dan Diare biasanya penyebarannya memulai hidup tidak sehat lingkungan kotor sehingga banyak bakteri dan virus yang mengarah diare.

Untuk itu patut diketahui masing-masing daerah memiliki penyebaran jenis penyakit mana yang paling dominan pada puskesmas perkecamatan kota Tangerang, pengklasteran pada jenis penyakit menular dengan metode Algoritma K-means Klaster dapat diketahui jenis penyakit dan daerah penyebarannya. Dengan demikian, masalah yang dapat diidentifikasi adalah Bagaimana Pembentukan Klaster atau Clustering jenis penyakit pada Puskesmas perkecamatan di Kota Tangerang untuk memudahkan penanganan dan perbaikan lingkungan. Serta mencari jenis penyakit mana yang paling dominan pada masing-masing klaster, saat mengklusterkan pada puskesmas perkecamatan di Kota Tangerang. pembatasan masalah dalam penelitian ini yaitu: objek penelitian ini adalah Jenis Penyakit pada Puskesmas setiap Kecamatan di Kota Tangerang; Pengklasteran yang dipengaruhi Jumlah penduduk, kepadatan penduduk, dan jenis penyakit yang di derita pada puskesmas perkecamatan di Kota Tangerang; Subjek penelitian ini adalah hasil dari Pengklasteran Jenis Penyakit pada Puskesmas perkecamatan di Kota Tangerang; Metode yang digunakan adalah Analisis Klaster Menggunakan Algoritma K-means Klaster dengan perhitungan menggunakan Aplikasi SPSS 22.

\section{DATA DAN METODE}

\subsection{Data dan Lokasi}

Data yang digunakan dalam penelitian ini marupakan data Sekunder yaitu berupa data yang dikumpulkan dari sumber BPS Kota Tangerang dengan nama Publikasi Katalog Kecamatan dalam Angka melalui web https://tangerangkota.bps.go.id. sumber data sudah berbentuk dalam dokumen yang peneliti jadikan sebagai populasi dan sampel. Berikut adalah tabel data yang akan diklasterkan. 
Tabel 2.1 data

\begin{tabular}{|c|c|c|c|c|c|c|c|c|}
\hline \multirow{2}{*}{ No. } & \multirow{2}{*}{ Kecamatan } & \multirow{2}{*}{ Puskesmas } & \multirow{2}{*}{\begin{tabular}{|c|} 
Jumlah \\
Penduduk
\end{tabular}} & \multirow{2}{*}{\begin{tabular}{|l|} 
Ke padatan \\
Penduduk
\end{tabular}} & \multicolumn{4}{|c|}{ Jenis Penyakit Menular } \\
\hline & & & & & TB. Paru & Pnumonia & DBD & Diare \\
\hline 1 & \multirow{2}{*}{ Batu Ceper } & Batu Ceper & 57924 & 57351 & 31 & 116 & 8 & 1296 \\
\hline 2 & & Poris Gaga & 43462 & 43032 & 64 & 180 & 7 & 1384 \\
\hline 3 & \multirow{2}{*}{ Benda } & Jurumudi Baru & 45049 & 20555 & 19 & 155 & 1 & 1504 \\
\hline 4 & & Benda & 100059 & 57118 & 22 & 143 & 3 & 789 \\
\hline 5 & \multirow{2}{*}{ Cibodas } & Cibodasari & 70461 & 64513 & 52 & 260 & 23 & 715 \\
\hline 6 & & Baja & 153768 & 106488 & 97 & 240 & 16 & 420 \\
\hline 7 & \multirow{2}{*}{ Ciledug } & Tajur & 104708 & 89211 & 46 & 107 & 11 & 643 \\
\hline 8 & & Ciledug & 87683 & 91563 & 75 & 142 & 5 & 692 \\
\hline 9 & \multirow{2}{*}{ Cipondoh } & Gondrong & 117197 & 36264 & 11 & 153 & 26 & 983 \\
\hline 10 & & Ketapang & 155801 & 50819 & 28 & 294 & 41 & 946 \\
\hline 11 & Jatiuwung & Jatiuwung & 124066 & 62121 & 39 & 461 & 36 & 543 \\
\hline 12 & \multirow{2}{*}{ Karang Tengah } & Pondok Bahar & 67521 & 53814 & 28 & 69 & 8 & 408 \\
\hline 13 & & Karang Tengah & 126315 & 108794 & 51 & 708 & 12 & 1221 \\
\hline 14 & \multirow{4}{*}{ Karawaci } & Pabuaran Tumpeng & 69137 & 151604 & 40 & 250 & 18 & 734 \\
\hline 15 & & Bugel & 68482 & 69010 & 15 & 126 & 20 & 308 \\
\hline 16 & & Karawaci Baru & 43172 & 44859 & 42 & 221 & 32 & 1089 \\
\hline 17 & & Pasar Baru & 30407 & 90704 & 9 & 55 & 9 & 290 \\
\hline 18 & \multirow{2}{*}{ Larangan } & Larangan Utara & 198950 & 171267 & 35 & 163 & 3 & 1441 \\
\hline 19 & & Cipadu & 94177 & 76435 & 70 & 168 & 21 & 1625 \\
\hline 20 & \multirow{2}{*}{ Neglasari } & Neglasari & 70424 & 35658 & 58 & 321 & 5 & 1666 \\
\hline 21 & & Kedaung Wetan & 46128 & 23457 & 18 & 192 & 8 & 999 \\
\hline 22 & \multirow{3}{*}{ Periuk } & Periuk Jaya & 50136 & 2766 & 45 & 182 & 0 & 1031 \\
\hline 23 & & \begin{tabular}{|l|} 
Sangiang Jaya \\
\end{tabular} & 27103 & 2657 & 34 & 67 & 9 & 651 \\
\hline 24 & & Gembor & 69581 & 3434 & 48 & 116 & 16 & 1762 \\
\hline 25 & \multirow{3}{*}{ Pinang } & Kunciran & 112486 & 71928 & 23 & 197 & 2 & 1335 \\
\hline 26 & & \begin{tabular}{|l|} 
Kunciran Baru \\
\end{tabular} & 84262 & 36984 & 15 & 141 & 10 & 937 \\
\hline 27 & & Panunggangan & 186932 & 108752 & 42 & 180 & 8 & 1162 \\
\hline 28 & \multirow{3}{*}{ Tangerang } & \begin{tabular}{|l} 
Sukasari \\
\end{tabular} & 54673 & 32288 & 36 & 121 & 27 & 474 \\
\hline 29 & & Tanah Tinggi & 51704 & 37207 & 29 & 253 & 22 & 1329 \\
\hline 30 & & Cikokol & 72958 & 28473 & 22 & 162 & 28 & 504 \\
\hline
\end{tabular}

\subsection{Metode Analisis}

Analisis data pengklasteran menggunakan Non-Hirarchical Cluster dengan metode penentuan kelompok Algoritma K-means Cluster. metode ini justru dimulai dengan terlebih dahulu jumlah klaster yang diinginkan (dua klaster, tiga klaster atau yang lain) sampai terbentuknya klaster.

Dari data di atas akan di cari empat klaster dengan menggunakan aplikasi SPSS 22 dan untuk menguji klaster yang telah ditentukan sudah akurat akan membuat chart yang menunjukan distribusi normal, matriks similarity, dan korelasi data.

Dari gambar chart di berikut, data yang dipakai yaitu jumlah puskesmas dengan angka penyakit memiliki data berdistribusi normal demikian untuk variabelnya pun memiliki karakteristik-karaterristik yang berbeda tetapi tetap berdistribusi normal. 


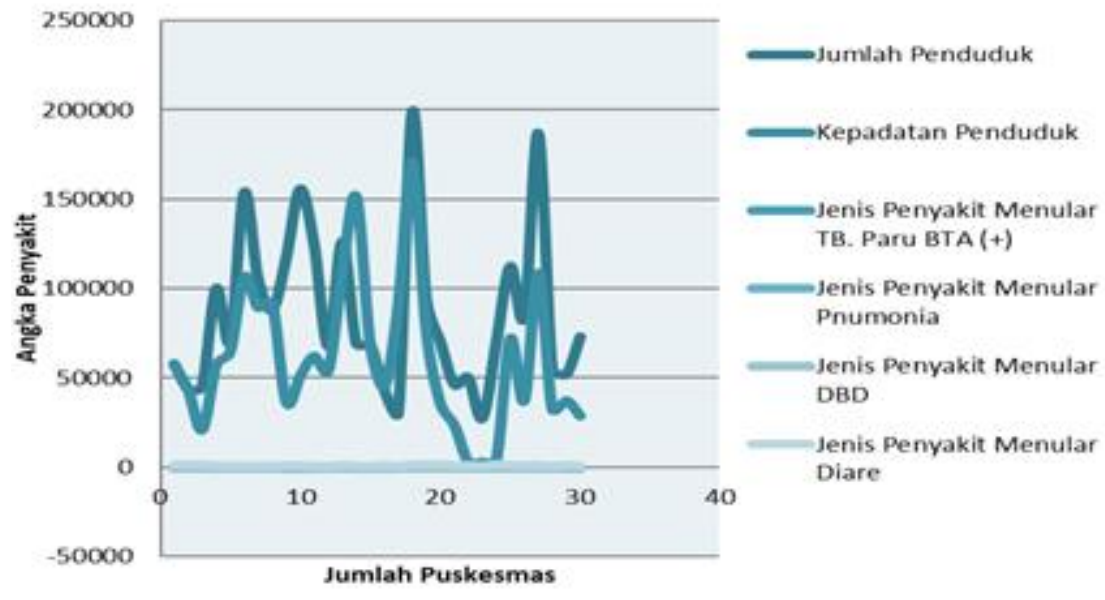

Gambar 2.1. Gambar Chart Berdistribusi Normal

Ukuran kesamaan atau (similarity) pada data menggunakan kesamaan jarak antara titik pada data puskesmas memiliki kesamaan yang berbeda jadi untuk pengujian metode analisis klaster dengan empat klaster yang akan dibentuk dapat dilakukan.

Tabel 2.2 Korelasi

\begin{tabular}{|c|c|c|c|c|c|c|c|c|}
\hline \multicolumn{9}{|c|}{ Correlations } \\
\hline \multicolumn{3}{|l|}{ Control Variables } & $\begin{array}{l}\text { Jumlah } \\
\text { Penduduk }\end{array}$ & $\begin{array}{l}\text { Kepadatan } \\
\text { Penduduk }\end{array}$ & TB.Paru & Pneumonia & DBD & Diare \\
\hline \multirow[t]{18}{*}{- none- $^{\mathrm{a}}$} & \multirow[t]{3}{*}{ Jumlah Penduduk } & Correlation & 1.000 & .614 & .210 & .321 & .099 & .088 \\
\hline & & Significance (2-tailed) & & .000 & .266 & .083 & .601 & .642 \\
\hline & & df & 0 & 28 & 28 & 28 & 28 & 28 \\
\hline & \multirow[t]{3}{*}{ Kepadatan Penduduk } & Correlation & .614 & \multirow[t]{2}{*}{1.000} & .251 & .228 & -.089 & -.116 \\
\hline & & Significance (2-tailed) & .000 & & .182 & .226 & .641 & .540 \\
\hline & & df & 28 & 0 & 28 & 28 & 28 & 28 \\
\hline & \multirow[t]{3}{*}{ TB.Paru } & Correlation & .210 & .251 & 1.000 & .260 & -.034 & .156 \\
\hline & & Significance (2-tailed) & .266 & .182 & & .165 & .860 & .411 \\
\hline & & df & 28 & 28 & 0 & 28 & 28 & 28 \\
\hline & \multirow[t]{3}{*}{ Pneumonia } & Correlation & .321 & .228 & .260 & 1.000 & .267 & .176 \\
\hline & & Significance (2-tailed) & .083 & .226 & .165 & & .154 & .353 \\
\hline & & df & 28 & 28 & 28 & 0 & 28 & 28 \\
\hline & \multirow[t]{3}{*}{ DBD } & Correlation & .099 & -.089 & -.034 & .267 & 1.000 & -.266 \\
\hline & & Significance (2-tailed) & .601 & .641 & .860 & .154 & & .155 \\
\hline & & df & 28 & 28 & 28 & 28 & 0 & 28 \\
\hline & \multirow[t]{3}{*}{ Diare } & Correlation & .088 & -.116 & .156 & .176 & -.266 & 1.000 \\
\hline & & Significance (2-tailed) & .642 & .540 & .411 & .353 & .155 & \\
\hline & & df & 28 & 28 & 28 & 28 & 28 & 0 \\
\hline \multirow{6}{*}{$\begin{array}{l}\text { TB.Paru \& Pneumonia \& } \\
\text { DBD \& Diare }\end{array}$} & \multirow[t]{3}{*}{ Jumlah Penduduk } & Correlation & \multirow[t]{3}{*}{1.000} & .614 & & & & \\
\hline & & Significance (2-tailed) & & .001 & & & & \\
\hline & & df & & 24 & & & & \\
\hline & \multirow[t]{3}{*}{ Kepadatan Penduduk } & Correlation & 614 & \multirow[t]{3}{*}{1.000} & & & & \\
\hline & & Significance (2-tailed) & .001 & & & & & \\
\hline & & df & 24 & & & & & \\
\hline
\end{tabular}

a. Cells contain zero-order (Pearson) correlations.

Dari tabel korelasi di atas antara variabel TB Paru, Pneumonia, DBD, Diare dengan Jumlah Penduduk dan Kepadatan Penduduk memiliki angka 0.614 angka ini menunjukan adanya korelasi yang cukup kuat dan positif atau searah. Ini berarti keterhubungan masih cukup untuk dilakukan pengujian analisis klaster karena saling terarah. 


\subsection{Interpretasi Analisis Klaster}

penelitian ini dilakukan untuk clustering jenis penyakit menular pada Puskesmas Kota Tangerang dengan data dari BPS Kota Tangerang, dokumen publikasi dengan nama Katalog Kecamatan dalam Angka 2018 pada bulan April-Mei 2019. Data 13 Kecamatan 30 Puskesmas yang akan di klasterkan menjadi empat Klaster dengan Klaster 1 : TB Paru Klaster 2 : Pneumonia Klaster 3 : DBD Klaster 4 : Diare.

Untuk itu agar dapat terbentuk klaster yang diinginkan akan diujikan memakai aplikasi SPSS 22 dengan interpretasi analisis klaster menggunakan metode K-means Cluster yang akan dibahas di bawah ini :

Tabel 2.3 Descriptive Statistics

\begin{tabular}{|l|r|r|r|c|r|}
\hline & N & Minimum & Maximum & Mean & Std. Deviation \\
\hline Jumlah Penduduk & 30 & 27103 & 198950 & 86157.53 & 44464.948 \\
Kepadatan Penduduk & 30 & 2657 & 171267 & 60970.87 & 40789.569 \\
TB.Paru & 30 & 9 & 97 & 38.13 & 20.384 \\
Pneumonia & 30 & 55 & 708 & 198.10 & 127.336 \\
DBD & 30 & 0 & 41 & 14.50 & 10.951 \\
Diare & 30 & 290 & 1762 & 962.70 & 427.916 \\
Valid N (listwise) & 30 & & & & \\
\hline
\end{tabular}

Keluaran tabel ini untuk membantu pengelompokan klaster dengan Zscore yang dihasilkan pada uji ini. Sehingga dapat menganalisa kluster yang terbentuk nantinya melalui Zscore.

Tabel 2.4 Initial Cluster Centers

\begin{tabular}{|l|r|r|r|r|}
\hline \multirow{2}{*}{} & \multicolumn{4}{|c|}{ Cluster } \\
\cline { 2 - 5 } & \multicolumn{1}{|c|}{1} & \multicolumn{1}{|c|}{2} & \multicolumn{1}{c|}{3} \\
\hline Zscore: Jumlah & -1.25381 & 2.53666 & .85255 & -.37280 \\
Penduduk & & & & \\
Zscore: Kepadatan & .72894 & 2.70403 & .02820 & -1.41058 \\
Penduduk & & & & \\
Zscore(TB.Paru) & -1.42924 & -.15372 & .04252 & .48404 \\
Zscore(Pneumonia) & -1.12380 & -.27565 & 2.06462 & -.64475 \\
Zscore(DBD) & -.50226 & -1.05018 & 1.96338 & .13698 \\
Zscore(Diare) & -1.57204 & 1.11774 & -.98080 & 1.86789 \\
\hline
\end{tabular}

Pada tabel initial cluster centers ini merupakan proses pertama untuk pengelompokan data aplikasi SPSS 22. Karena pengelompokan data ini merupakan proses untuk pembentukan empat kluster secara kasarnya untuk melihat pembentukan klaster lihat pada tabel berikut: 
Tabel 2.5 Iteration History

\begin{tabular}{|l|r|r|r|r|}
\hline \multirow{2}{*}{ Iteration } & \multicolumn{4}{|c|}{ Change in Cluster Centers } \\
\cline { 2 - 5 } & 1 & 2 & \multicolumn{1}{c|}{4} \\
\hline 1 & 1.826 & .893 & 1.460 & 1.542 \\
2 & .183 & .000 & .000 & .211 \\
3 & .000 & .000 & .000 & .000 \\
\hline
\end{tabular}

a. Convergence achieved due to no or small change in cluster centers. The maximum absolute coordinate change for any center is .000. The current iteration is 3 . The minimum distance between initial centers is 4.635.

Tabel di atas adalah tabel iteration history yaitu proses pengelompokan kluster melalui iterasi untuk membaca tabel ini, karena menggunakan $K$-means Cluster tabel ini menjelaskan bahwa melalui proses iterasi dengan gambaran tabel iterasi di atas iterasi terjadi 3 kali, karena pada iterasi $1=$ centeroid tidak signifikan iterasi $2=$ nilai centeroid hampir signifikan iterasi $3=$ centeroid berada dalam signifikan semua maka klaster sudah terbentuk dan iterasi stop. dengan kluster yang telah ditentukan yaitu empat kluster memilki proses iterasi sebanyak 3 kali iterasi dengan jarak minimum 4.635 .

\section{HASIL DAN DISKUSI}

\subsection{Validasi Analisis Klaster}

Validasi analisis klaster ini dapat dilihat pada tabel 3.1 cluster membership dari interpretasi yang tafsirkan bahwa klaster terbentuk melalui tiga kali iterasi, disini akan dibahas hasil validasi dari iterasi tersebut sehingga terbentuk klaster pada tabel berikut ini :

Tabel 3.1 Cluster Membership

Cluster Membership

\begin{tabular}{|l|r|r|}
\hline Case Number & Cluster & Distance \\
\hline 1 & 4 & .956 \\
2 & 4 & 1.287 \\
3 & 4 & 1.578 \\
4 & 1 & 1.332 \\
5 & 3 & 1.687 \\
6 & 3 & 2.881 \\
7 & 1 & 1.318 \\
8 & 1 & 2.536 \\
9 & 1 & 2.008 \\
10 & 3 & 2.283 \\
11 & 3 & 1.460 \\
12 & 1 & .932 \\
13 & 3 & 3.059 \\
14 & 1 & 2.498 \\
15 & 1 & 1.150 \\
\hline
\end{tabular}

Cluster Membership

\begin{tabular}{|l|r|r|}
\hline Case Number & Cluster & Distance \\
\hline 16 & 4 & 2.082 \\
17 & 1 & 1.904 \\
18 & 2 & .893 \\
19 & 4 & 2.169 \\
20 & 4 & 1.615 \\
21 & 4 & 1.517 \\
22 & 4 & 1.582 \\
23 & 1 & 1.930 \\
24 & 4 & 1.509 \\
25 & 4 & 1.849 \\
26 & 1 & 1.288 \\
27 & 2 & .893 \\
28 & 1 & 1.491 \\
29 & 4 & 1.272 \\
30 & 1 & 1.567 \\
\hline
\end{tabular}

Keluaran dari tabel 3.1 Cluster Membership dapat dikatakan hasil akhir klaster dengan aplikasi SPSS 22, yang menggunakan iterasi sebanyak tiga kali iterasi. 


\subsection{Profiling Analisis Klaster}

Dari hasil validasi yang dapat dilihat pada tabel 3.1 selanjutnya adalah Profiling sehingga dapat dilihat untuk klaster pertama terbagi menjadi 12 Puskesmas, klaster kedua terbagi dalam 2 Puskesmas, klaster ketiga ada pada 5 Puskesmas, dan untuk klaster keempat terbagi pada 11 Puskesmas, dimana terjadi pengelompokan di Puskesmas Perkecamatan masing-masing klaster yang dijelaskan pada tabel dibawah ini:

Tabel 3.2 Hasil Akhir Klaster Pada Puskesmas

\begin{tabular}{|c|c|c|c|c|}
\hline Data ke-i & Klaster 1 & Klaster 2 & Klaster 3 & Klaster 4 \\
\hline 1 & & & & Batu Ceper \\
\hline 2 & & & & Poris Gaga \\
\hline 3 & & & & Jurumudi Baru \\
\hline 4 & Benda & & & \\
\hline 5 & & & Cibodasari & \\
\hline 6 & & & Baja & \\
\hline 7 & Tajur & & & \\
\hline 8 & Ciledug & & & \\
\hline 9 & Gondrong & & & \\
\hline 10 & & & Ketapang & \\
\hline 11 & & & Jatiuwung & \\
\hline 12 & Pondok Bahar & & & \\
\hline 13 & & & Karang Tengah & \\
\hline 14 & $\begin{array}{l}\text { Pabuaran } \\
\text { Tumpeng }\end{array}$ & & & \\
\hline 15 & Bugel & & & \\
\hline 16 & & & & Karawaci Baru \\
\hline 17 & Pasar Baru & & & \\
\hline 18 & & Larangan Utara & & \\
\hline 19 & & & & Cipadu \\
\hline 20 & & & & Neglasari \\
\hline 21 & & & & $\begin{array}{l}\text { Kedaung } \\
\text { Wetan }\end{array}$ \\
\hline Data ke-i & Klaster 1 & Klaster 2 & Klaster 3 & Klaster 4 \\
\hline 22 & & & & Periuk Jaya \\
\hline 23 & Sangiang Jaya & & & \\
\hline 24 & & & & Gembor \\
\hline 25 & & & & Kunciran \\
\hline 26 & Kunciran Baru & & & \\
\hline 27 & & Panungangan & & \\
\hline 28 & Sukasari & & & \\
\hline 29 & & & & Tanah Tinggi \\
\hline 30 & Cikokol & & & \\
\hline
\end{tabular}

Tabel 3.2 menunjukkan Hasil Akhir Klaster Pada Puskesmas dan dapat diartikan dengan profiling sebagai berikut : 


\section{Klaster 1}

TB Paru adalah penamaan untuk klaster 1 maka dari itu klaster 1 hasil akhir pengklasteran mendapatkan 12 Puskesmas dengan nama daerah puskesmas yang terbagi klaster 1 yaitu : Puskesmas Benda memiliki jarak 1.332, Puskesmas Tajur memiliki jarak 1.318, Puskesmas ciledug memiliki jarak 2.536, Puskesmas Gondrong memiliki jarak 2.008, Puskesmas Pondok Bahar memiliki jarak 0.932, Puskesmas Pabuaran Tumpeng memiliki jarak 2.498, Puskesmas Bugel memiliki jarak 1.150, Puskesmas Pasar Baru memiliki jarak 1.904, Puskesmas Sangiang Jaya memiliki jarak 1.930, Puskesmas Kunciran Baru memiliki jarak 1.288, Puskesmas Sukasari memiliki jarak 1.491, dan Puskesmas Cikokol memiliki jarak 1.567. dengan jarak pada masing-masing klaster yang paling dominan adalah Puskesmas Ciledug dengan jarak antar titik memiliki 2.536 dengan jumlah penderita TB Paru sebanyak 75 orang, jumlah penduduk 87683, kepadatan penduduk 91563. Untuk itu dengan kepadatan penduduknya melebihi jumlah pada suatu daerah artinya penduduk tersebut memiliki kepadatan pada daerahnya sehingga ruang untuk penyebaran penyakit TB Paru ini dapat mudah menular. dari masing-masing puskesmas yang terdapat pada klaster 1 puskesmas ciledug lah yang memiliki paling banyak menderita penyakit TB Paru ini.

2. Klaster 2

Pneumonia adalah penamaan untuk klaster 2 maka dari itu klaster 2 hasil akhir pengklasteran mendapatkan 2 Puskesmas saja, dengan nama daerah puskesmas yang terbagi klaster 2 yaitu : Puskesmas Larangan Utara memiliki jarak 0.893, dan Puskesmas Panunggangan memiliki jarak 0.893, dengan jarak yang sama sehingga karakteristik kedua puskesmas sama tetapi memiliki kasus penderita pneumonia yang berbeda. Untuk Puskesmas Panunggangan ada 180 kasus dan Puskesmas Larangan Utara 165 kasus, sehingga pada klaster 2 Puskesmas yang paling dominan adalah Puskesmas Panunggan dengan 180 kasus.

3. Klaster 3

DBD adalah penamaan untuk klaster 3 maka dari itu klaster 3 hasil akhir pengklasteran mendapatkan 5 Puskesmas dengan nama daerah puskesmas yang terbagi klaster 3 yaitu : Puskesmas Cibodasari memiliki jarak 1.687, Puskesmas Baja jarak 2.881, Puskesmas Ketapang memiliki jarak 2.283, Puskesmas Jatiuwung memiliki jarak 1.460, dan Puskesmas Karang Tengah memiliki jarak 3.059. dengan jarak pada masing-masing klaster yang paling dominan adalah Puskesmas Ketapang dengan jarak antar titik memiliki 2.283 dengan jumlah penderita DBD sebanyak 41 orang, jumlah penduduk 155801, kepadatan penduduk 50819. dengan jumlah yang terjangkit penyakit DBD lebih banyak dari puskesmas lainnya yang berada di klaster 3 yaitu berjumlah 41 orang.

4. Klaster 4

Diare adalah penamaan untuk klaster 4 maka dari itu klaster 4 hasil akhir pengklasteran mendapatkan 11 Puskesmas dengan nama daerah puskesmas yang terbagi klaster 4 yaitu : Puskesmas Batu Ceper memiliki jarak 0.956, Puskesmas Poris Gaga memiliki jarak 1.287, Puskesmas Jurumudi Baru memiliki jarak 1.578, Puskesmas Karawaci Baru memiliki jarak 2.082, Puskesmas Cipadu memiliki jarak 2.169, Puskesmas Neglasari memiliki jarak 1.615, Puskesmas Kedaung Wetan memiliki jarak 1.517, Puskesmas Periuk Jaya memiliki jarak 1.582, Puskesmas Gembor memiliki jarak 1.509, Puskesmas Kunciran memiliki jarak 1.849, dan Puskesmas Tanah Tinggi memiliki jarak 1.272. dengan jarak pada masing-masing klaster yang paling dominan adalah Puskesmas gembor dengan jarak antar titik memiliki 1.509 
dengan jumlah penderita Diare sebanyak 1762 orang, jumlah penduduk 69581, kepadatan penduduk 3434.

Untuk Lebih Detail lagi keluaran tabel selanjutnya akan membahas centeroid pada Hasil klaster yang telah dibentuk pada aplikasi SPSS 22 berikut adalah tabel 4.9 Final Cluster Centers:

Tabel 3.3 Final Cluster Centers

\begin{tabular}{|l|r|r|r|r|}
\hline \multirow{2}{*}{} & \multicolumn{4}{|c|}{ Cluster } \\
\cline { 2 - 5 } & 1 & \multicolumn{1}{|c|}{2} & \multicolumn{1}{c|}{3} \\
\hline Zscore: Jumlah & -.28056 & 2.40152 & .89789 & -.53871 \\
Penduduk & & & & \\
Zscore: Kepadatan & .01642 & 1.93772 & .43090 & -.56609 \\
Penduduk & -.42763 & .01799 & .74896 & .12280 \\
Zscore(TB.Paru) & -.55051 & -.20890 & 1.52746 & -.05576 \\
Zscore(Pneumonia) & .00000 & -.82188 & 1.01365 & -.31132 \\
Zscore(DBD) & -.80612 & .79174 & -.45266 & .94120 \\
Zscore(Diare) & \multicolumn{4}{|l}{} \\
\hline
\end{tabular}

Pembacaan tabel diatas merupakan proses akhir dari pengelompokan yang dilakukan, yaitu sebanyak empat klaster yang terbentuk untuk masing-masing variabel. Angka-angka yang dihasilkan terbentuk Titik Center pada Zscore yang telah diketahui sebelumnya dengan hasil akhir centeroid pada tabel diatas, untuk dapat membaca hasil akhir profiling antar variabel yang akan dibahas disini adalah hanya variabel Jumlah Penduduk dan Kepadatan Penduduk. Pengaruh kedua variabel tersebut dengan keempat klaster pada pengelompokan ini, dapat menggunakan rumus sebagai berikut:

$$
X=\mu+z . \sigma
$$

Keterangan :

$X=$ rata-rata sampel/data/variabel dalam klaster tertentu

$\mu=$ rata-rata populasi

$\sigma=$ standar deviasi

$z=$ nilai standarisasi

Berikut rata-rata populasi klaster 1,2,3, dan 4 dari variabel Jumlah Penduduk:

1. Klaster 1 :

Rata-rata Variabel $1+$ (nilai z klaster $1 \times$ standar deviasi rata-rata variabel 1$)=$ $86157,35+(-0,28056 \times 44464,948)=73682,444$

2. Klaster 2

Rata-rata Variabel $1+($ nilai z klaster $2 \times$ standar deviasi rata-rata variabel 1) $=$ $86157,35+(2,40152 \times 44464,948)=192940.991$

3. Klaster 3

Rata-rata Variabel $1+$ (nilai $\mathrm{z}$ klaster $3 \times$ standar deviasi rata-rata variabel 1$)=$ $86157,35+(0,89789 \times 44464,948)=126082.162$

4. Klaster 4 
Rata-rata Variabel $1+$ (nilai z klaster $4 \times$ standar deviasi rata-rata variabel 1 ) $=$ $86157,35+(-0,53187 \times 44464,948)=62203,818$

Dari perhitungan yang di dapat bahwa Variabel Jumlah Penduduk terdapat empat klaster. Klaster 1 sebesar 73682,444 berarti di bawah rata-rata populasi; untuk klaster 2192940.991 di atas rata-rata populasi; untuk klaster 3 sebesar 126082.162 di atas rata-rata populasi; dan klaster ke 4 sebesar 62203,818 dibawah rata-rata populasi. Rata-rata populasinya adalah 86175,53(lihat di tabel Descriptive Statistics). Maka Penduduk yang memiliki di bawah rata-rata populasi atau di bilang jumlah di bawah rata-rata mendapat pengelompokan jenis penyakit menular TB Paru dan diare, sedangkan penduduk yang di atas rata-rata populasi atau dapat dikatakan jumlah penduduk di atas rata-rata mendapat pengelompokan jenis penyakit menular Pneumonia dan DBD.

Berikut rata-rata populasi klaster 1,2,3, dan 4 dari variabel Kepadatan Penduduk:

1. Klaster 1 :

Rata-rata Variabel $2+$ (nilai z klaster $1 \times$ standar deviasi rata-rata variabel 2) = $60970,87+(0,1642 \times 40789,569)=67668,517$

2. Klaster 2

Rata-rata Variabel $2+$ (nilai z klaster $2 \times$ standar deviasi rata-rata variabel 2$)=$ $60970,87+(1,93772 \times 40789,569)=140009,634$

3. Klaster 3

Rata-rata Variabel $2+$ (nilai z klaster $3 \times$ standar deviasi rata-rata variabel 2) $=$ $60970,87+(0,43090 \times 40789,569)=78547,095$

4. Klaster 4

Rata-rata Variabel $2+$ (nilai z klaster $4 \times$ standar deviasi rata-rata variabel 2) = $60970,87+(-0,56609 \times 40789,569)=37880,303$

Dari perhitungan yang di dapat bahwa Variabel Kepadatan Penduduk terdapat empat klaster. Klaster 1 sebesar 67668,517 berarti di atas rata-rata populasi; untuk klaster 2 140009,634 di atas rata-rata populasi; untuk klaster 378547,095 sebesar di atas rata-rata populasi; dan klaster ke 4 sebesar 37880,303 dibawah rata-rata populasi. Rata-rata populasinya adalah 60970,87 (lihat di tabel Descriptive Statistics). Maka Penduduk yang memiliki di bawah rata-rata populasi atau di bilang Kepadatan Penduduk di bawah rata-rata mendapat pengelompokan jenis penyakit menular diare, sedangkan penduduk yang di atas rata-rata populasi atau dapat dikatakan Kepadatan penduduk di atas rata-rata mendapat pengelompokan jenis penyakit menular TB Paru, Pneumonia, dan DBD.

\subsection{Asumsi-asumsi Analisis Klaster}

Asumsi-asumsi pada analisis multivariate biasanya menggunakan uji normalitas, uji linearitas, dan uji heteroskedastisitas. Untuk asumsi pada Analisis Klaster biasanya memkai uji ANOVA untuk melakukan pengujian secara signifikan antar klaster. Berikut tabel 4.10 ANOVA: 
Tabel 3.4. ANOVA

\begin{tabular}{|c|c|c|c|c|c|c|}
\hline \multicolumn{7}{|c|}{ ANOVA } \\
\hline & \multicolumn{2}{|c|}{ Cluster } & \multicolumn{2}{|c|}{ Error } & \multirow[b]{2}{*}{$\mathrm{F}$} & \multirow[b]{2}{*}{ Sig. } \\
\hline & Mean Square & df & Mean Square & df & & \\
\hline $\begin{array}{l}\text { Zscore: Jumlah } \\
\text { Penduduk }\end{array}$ & 6.567 & 3 & .358 & 26 & 18.366 & .000 \\
\hline $\begin{array}{l}\text { Zscore: Kepadatan } \\
\text { Penduduk }\end{array}$ & 3.989 & 3 & .655 & 26 & 6.088 & .003 \\
\hline Zscore(TB.Paru) & 1.722 & 3 & .917 & 26 & 1.878 & .158 \\
\hline Zscore(Pneumonia) & 5.141 & 3 & .522 & 26 & 9.846 & .000 \\
\hline Zscore(DBD) & 2.518 & 3 & .825 & 26 & 3.053 & .046 \\
\hline Zscore(Diare) & 6.607 & 3 & .353 & 26 & 18.713 & .000 \\
\hline
\end{tabular}

Tabel ANOVA digunakan untuk melihat tingkat signifikansi antar klaster. Kolom klaster merupakan besaran between cluster means dan kolom Error merupakan within cluster means. Sementara itu, nilai kolom $\mathrm{F}$ diperoleh melalui rumus berikut :

$$
F=\frac{\text { between means }}{\text { within means }}
$$

Ketentuan penggunaan angka $\mathrm{F}$ dalam analisis klaster ialah bahwa semakin besar angka $\mathrm{F}$ hitung (jika dilakukan uji Hipotesis, maka F hitung akan lebih besar dari F tabel) dan tingkat signifikansi (sig) $<0,05$; maka semakin besar perbedaan antara ketiga klaster yang terbentuk.

Untuk itu peneliti akan membuat hipotesis pengujian sebagai berikut :

Merumuskan Hipotesis :

$H_{0}$ : Keempat klaster tidak mempunyai perbedaan yang signifikan.

$H_{1}$ : Keempat klaster mempunyai perbedaan yang signifikan.

Jika angka signifikan $>0.05 ; H_{0}$ diterima $H_{1}$ ditolak

Jika angka signifikan $<0,05 ; H_{0}$ ditolak $H_{1}$ diterima

$$
F=\frac{18,366}{0,358}=51,30
$$

Jika dilihat dari perhitungan variabel 1 hasil $\mathrm{F}$ hitung $>\mathrm{F}$ tabel maka dengan angka 51,30 $>$ 18,366 dan signifikansi 0,000; maka $H_{0}$ ditolak $H_{1}$ diterima. Artinya, keempat klaster mempunyai perbedaan yang signifikan. Dan dari semua variabel hampir mempunya signifikansi $<0,05$ maka dari keseluruhan dapat dikatakan mempunyai perbedaan yang signifikan.

Dengan demikian hasil klaster yang di dapat dalam penelitian ini bahwa untuk pengelompokan jenis penyakit menular menunjukkan adanya perbedaan pada keempat klaster yang terbentuk. Hal ini dengan ditunjukkannya nilai $F=52,30$ dan sig $=0,001$. Selanjutnya untuk mengetahui jumlah anggota masing-masing klaster yang terbentuk dapat dilihat pada tabel berikut ini: 
Tabel 4.11 Number of Cases in Each Cluster

\begin{tabular}{|ll|r|}
\hline Cluster & 1 & 12.000 \\
& 2 & 2.000 \\
& 3 & 5.000 \\
& 4 & 11.000 \\
Valid & & 30.000 \\
Missing & & .000 \\
\hline
\end{tabular}

Nampak jelas bahwa klaster 1 beranggotakan 12 Puskesmas, klaster 2 beranggotakan 2 Puskesmas, klaster 3 beranggotakan 5 Puskesmas dan untuk klaster 4 beranggotakan 11 Puskesmas.

\section{KESIMPULAN}

Penelitian ini menghasilkan empat klaster dengan profiling klaster 1 TB Paru klaster 2 Pneumonia klaster 3 DBD klaster 4 Diare. Proses terbentuknya klaster-klaster tersebut adalah dengan iterasi-iterasi yang dilakukan, pada penentuan klaster ini terjadi 3 kali iterasi yang dilakukan sehingga mendapat hasil nilai minimum yang sampai terbentuk keempat klaster tersebut, dengan nilai minimum akhir 4.635. TB Paru adalah penamaan untuk klaster 1 maka dari itu klaster 1 hasil akhir pengklasteran mendapatkan 12 Puskesmas, Pneumonia adalah penamaan untuk klaster 2 maka dari itu klaster 2 hasil akhir pengklasteran mendapatkan 2 Puskesmas, DBD adalah penamaan untuk klaster 3 maka dari itu klaster 3 hasil akhir pengklasteran mendapatkan 5 Puskesmas, Diare adalah penamaan untuk klaster 4 maka dari itu klaster 4 hasil akhir pengklasteran mendapatkan 11 Puskesmas. 3. Klaster yang paling dominan dari klaster yang terbentuk adalah Klaster 1.

\section{REFERENSI}

Hasan, M. I. (2002). Pokok-pokok Metodelogi Penelitian dan Aplikasinya. Jakarta: Ghalia Indonesia.

Martono, N. (2011). Metode Penelitian Kuantitatif: Analisis Isi dan Analisis Data Sekunder. Jakarta: PT.Raja Grafindo Persada.

Prof. Dr. Sugiono. (2013). Statistika Dalam Penelitian. Bandung: ALFABETA.

Prof. Gundono, Ph.D. CMA. (2017). Analisis Data Multivariat. Yogyakarta: BPFE.

Sarwono, J. (2015). Rumus-rumus Populer dalam SPSS 22 untuk Riset Skripsi. Yogyakarta: ANDI.

Sugiono. (2009). Penelitian Kuantitatif Kualititatif dan R\&D. Bandung: ALFABETA.

Suharsimi. (2002). Metodelogi Penelitian. Yogyakarta: ALFABETA.

\section{PUSTAKA DARI INTERNET}

B.J, P. (2008, Desember Senin). Analisis Cluster. Retrieved Mei Minggu, 2019, from prayudho.wordpress.com: https://prayudho.wordpress.com/2008/12/30/analisis-cluster/ 
Badan Pusat Statistik kota Tangerang. (2017). Statistik daerah kota Tangerang. Kota Tangerang: CV.Dharma Putra.

depkes.go.id. (2004). Sejarah Puskesmas. Depkes.

Dr. Kevin Adrian. (2018, September Jumat). Penyakit menular yang umum di indonesia. Retrieved April Senin, 2019, from alodokter: http://www.alodokter.com

Dr. Tjin Willy. (2018, Desember Jumat). Pneumonia. Retrieved April Senin, 2019, from alodokter: http://www.alodokter.com

Hidayat, A. (2014, Maret). Statistikian. Retrieved Februari Senin, 2019, from www.statistikian.com: https://www.statistikian.com/2014/03/analisis-cluster.html/amp

Kementrian kesehatan. (2010, September Rabu). PusDatin. Retrieved May Senin, 2019, from www.pudatin.kemkes.go.id: http://www.pusdatin.kemkes.go.id

Kementrian Kesehatan RI. (2015). Hari Tuberkulosis Sedunia. Jakarta: InfoDATIN. 